\title{
MODERN ASTRONOMY IN INDO - PERSIAN SOURCES
}

\author{
S. M. RAZAULLAH ANSARI \\ Physics Dept. Aligarh Muslim University, Aligarh (India)
}

The Period from 1858 to 1947 is known as the British Period of Indian History. After the fall of Mughal empire, when the first war of independence against British colonisers failed in 1857, and the East India Company's Government was transferred to the British Crown in 1858. However only in 1910, a Department of Education was established by the (British) Govt. of India and in the following decades modern universities were established in various important Indian towns, wherein Western / European type education and training with English as medium of instruction were imparted. However more than a century before, Indian scholar's came into contact with the scholars - administrators of East India Company, either through employment or social interaction. Thereby, Indians became acquainted with the scientific (also technological) advances in Europe. A few of them visited England and other European countries, Portugal, France etc. already in the last quarter of 18th century, in order to experience and to learn firsthand the European sciences.

In this paper, we report only the reception of European Astronomy by both Muslim and Hindu scholars who wrote in Indo-Persian - the official language, and scholars' lingua franca of the Mughal India. For instance, Mî̀ Muhammad Ḥusayn Landani ${ }^{1}$ (travelled 1774-77, d.1790), Qădị Najmuddìn Kākorwi (travelled 1795, d.1844), Mirzā Abu Țālib Landanī (travelled 1799-1803, d.1806), on one hand; and on the other hand astronomer-mathematician Ghulām Husayn Jawnp $\bar{u} \bar{i}$ (1790-1862) and the famous Hindu poet and scholar Raja Ratan Singh (1782-1851), all of whom wrote on Persian tracts on modern European astronomy, several decades before the official introduction of modern European Sciences in British India.

Mîr Muhammad Husayn was a famous Unani physician, poet and expert of rational sciences $\left({ }^{c} U t_{\bar{u} m-i}{ }^{c} A q T_{i} y a\right)$ of Murshidabad (Bengal). One of his British acquaintances was the famous Sir Henry Elliot. On his return from England and European, he wrote a tract in Arabic which was later translated in to Persian. The title is: "An Account of European and Modern World, along with some Problems of Modern Mathematics" (in Arabic), whereas in Persian version it is: "On the Theories of European Scholars concerning Planets and their Orbits" ${ }^{2}$. In this tract Mir Muliammad Husayn mentions Isaac Newton and N. Copernicus in connection with the telescope and the Solar System respectively. He stressed that the use of telescope had revolutionised astronomy, by observing thousands of "fixed" stars; elliptical bright rings around Saturn with its five satellites; thrce dark parallel lines on the surface of Jupiter, with its four satellites; phases of Venus, Sunspots; and inferior conjunctions (Muqārnah) of Venus and Mercury, the conjunctions being an evidence for their revolution around the Sun.

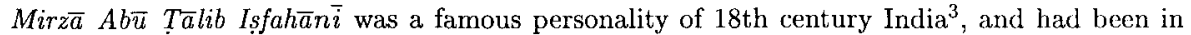
appointment of Nawab of Avadh, of the British Collector of Gorakhpur and of Resident of Lucknow. He wrote a number of tracts on Modern Astronomy (Hay'at-i Jadi $d)^{4}$. In his tract written after his return from Europe, he presented the most modern information regarding fixed stars, planets, satellites, comets, planetary heliocentric distances, orbital periods, diameter and speeds. He reported the then newly discovered planet Uranus (called then Georgium Sidus) and minor planets Ceres and Pallas. He reported specifically long period comets, i.e., of 75, 229 and 575 years. To note is that he was fully aware that the aforementioned information was not available to "ancient" astronomers and that it was achieved by means of "very long" telescopes.

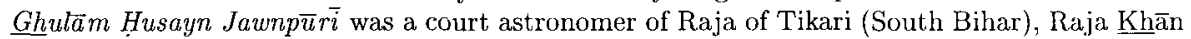
Bahādur Nușrat Jang - Muslim son of Maharaja Mitrājit Singh. He is credited with about half a dozen works concerning mathematics and astronomy. Out of these the most important are: "The

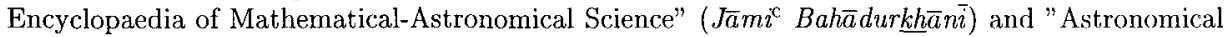




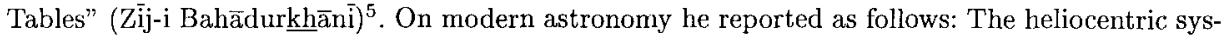
tem is illustrated in JB by a schematic diagram, wherein minor planets Pallas and Ceres between Mars and Jupiter, Uranus and the satellites around Jupiter, Saturn are shown excellently. He refers to the force of gravitation (after Newton) and elliptical orbits of the Earth etc. In ZB, his catalogue of stars is not confined to the customary 48 stellar constellations (after Ulugh Beg) but includes also 15 constellations of the southern sky. Further he observes that the rate of positional change of different starts is different in itself and thet due to such motions the shape and form of the constellations change and some stars move out of their constellations. All these facts he attributes to the observations by European astronomers.

All these efforts were in a way culminated in a treatise on modern astronomy: "Gardens of Astronomy" ( $H a d \bar{a}$ 'iq al-Nujüm) by Raja Ratan Singh. The treatise was written in 1837 and printed in 1840/1841. The Raja's family was in the service of the King of Avadh. He was a writer of repute ${ }^{6}$. In this excellently systematic treatise, he mentions the astronomical work/discoveries of Copernicus, Galileo, Kepler, Tycho Brahe, John Herschel, Cassini and Newton. The instruments mentioned are telescope (Dürbin, Sitärabīn), particularly Herschel's telescope of 16 yards, even micrometers and cross-wires. He informs about the establishment of Greenwich and Paris observatories. In his book, there are diagrams of Jupiter with bands Saturn with two rings, of phases of phases of Venus, of Mars and Uranus (called by him Georgius); and of the Sun with its spots. He has written a detailed chapter on Comets, wherein he mention particularly those which appeared in 1819, 1832 (Biela's Comet) and the one in 1835 which he observed himself. In fact, he gives a long list of comets recorded during 837-1835 AD There is even a chapter describing nebulaei $\left(S_{a h \bar{a}} b\right)$ and of course another one on fixed stars.

The works which have been summarised above are just a small selection from scores of Persian tracts concerning modern European astronomy, written particularly in the first half of the 19th century. It is a clear indicator that the Indian mind was quite receptive to the astronomy - the most modern Science of 18-19th centuries Europe. In fact, the initiator or predecessor of all these Indian Scholars was Raja Swai Jai Singh II (1686-1743), who is famous for his observatories in a number of Indian towns (Delhi, Jaipur etc.) and who sponsored the compilation of an astronomical table (Zijj-i Muhammad Sha $h \bar{i})$ which is mainly based on Phillipe de La Hire's astronomical tables, cf. David Pingree's contribution in these Proceedings. We intend to publish a comprehensive paper on this problématique elsewhere.

\section{Notes}

1. Landani is the epithet derived from the city of London, i.e., he visited London.

2. Ms of the Arabic version is extant in Aligarh, while Mss of the Persian version are in Hyderabad and Bombay.

3. His travelogue of European countries, written in Persian was translated into English, French and German before the publication of the Persian text (Calcutta, 1812).

4. Mss written in 1772 (in Hamadan/Iran ), in 1779 (in Rampur/India), in 1798 (in Aligarh/India) and a copy scribed in 1806 (in Aligarh and Edinburg) are extant. We use in the sequel the last one.

5. We abbreviate these titles as JB and ZB.

6. He is famous as a poet (nom de plume Zakhmi), literateur and a historian of the state of Avadh.

\section{Selected Bibliography}

Ansari, S.M.R., Modern Sciences in Indo-Persian Sources, Proceedings of the International Seminar on Persian Literature, Culture and History, held on Dec. 21-23, 1996 at Delhi University, in press.

Ansari, S.M.R., Indo-Persian Scientific Writing of Hindu Mathematician - A Brief Survey of Manuscript Sources, Proceedings of the National seminar on Late Mughals and Persian Literature (1707-1857), held at Persian Department, A.M.U. Aligarh, Sept 1995 (to be Published).

Ansari, S.M.R., The Indian Astronomer Ghulam Hussain Jaunpuri and his Zīj-i Bahādurkhān̄i, Studies in History of Medicine and Science, vol.14, New Series, No.1-2 (1995/96), pp.181-188.

Ansari, S.M.R, Introduction of Modern Western Astronomy in India during 18-19th Centuries, New Delhi, 1985. 